\title{
Dominant Factors Related To Use Of Male Condoms Of Man Who Have Sex With Men In Buleleng Regency
}

\author{
Putu Sukma Megaputri ${ }^{1}$, Ketut Putra Sedana ${ }^{1}$ \\ ${ }^{1}$ College of Buleleng Health Sciences
}

Email : megaputri_sukma@yahoo.com

Received : Nov 11 ${ }^{\text {th }}$ 2019. Revised : Oct $4^{\text {th }}$ 2019. Published: Dec $18^{\text {th }} 2019$

DOI : https://doi.org/10.22219/sm.Vol15.SMUMM2.8594

\begin{abstract}
Men who have sex with men(MSM) community had become one of the epicentrum of transmission of STIs and HIV / AIDS. The results of an integrated survey of biological behavior of MSM condom use are only less than $50 \%$. The objective of this study is to determine the most dominant factors increasing condom use in MSM. Survey Cross sectional study on MSM with a sample of 58 people selected by snowball sampling when MSM examined the Buleleng Health Center 1. Data collection was done by interviewing a questionnaire related to: social demographic characteristics, internal, external factors, negotiation and condom use. Data were analyzed by chi square followed by logistic regression using software. The study found that several factors related to condom use in MSM namely marital status showed that the respondents were unmarried (AOR: 9.5, 96\% CI 1.5-59.7). Then the perception of high MSM susceptibility was also related to condom use (AOR: 6.5, 96\% CI 1.3-33.3). Subsequently the availability of condoms on site and carried by MSM (AOR: 6.8, 96\% CI 1.1-45.6). Factors related to condom use in MSM in Buleleng Regency are unmarried status, condom availability and perceived susceptibility.
\end{abstract}

Keywords : MSM, Condom Use, Bali.

Copyright (C) 2019, First Author et al This is an open access article under the CC-BY-SA license

\section{INTRODUCTION}

Man who have sex with men (MSM) are now becoming main point of HIV / AIDS transmission. HIV / AIDS issues are still the main focus and concern of every country in the world. AIDS cases first discovered in America in MSM partners HIV prevalence in America, Southeast Asia to Sub-Saharan still reaches $14-18 \%$ in MSM(Beyrer, Baral, Sifakis, \& Cleghom, 2012). Surveillance data in middle income countryfound that men who have sex with men (MSM) are 19.3 times more at risk of HIV than the general population(Beyrer et al., 2012). Indonesia is currently still included in the country with the fifth highest risk of HIV / AIDS deaths (Kemenkes RI, 2014). The risk of HIV / AIDS does not only attack women with high-risk behaviors such as female sex workers, but also increasing risk for male sex offenders with men. This is because the 
sex behavior of MSM who frequently change partners becomes a risk of becoming STIs and HIV / AIDS (Chandra, Shaluhiyah, \& Cahyo, 2018).

Currently MSM is still a marginalized group, so it is difficult for this group to open up. So this is one of the causes of lack of health information and condom use during risky sexual intercourse. MSM community is very susceptible to transmit to their community, can also from other MSM transmit to their wives to their children, because this community has the potential as an epicentrum of HIV / AIDS transmission(Ruxrungtham, Brown, \& Phanuphak, 2004). At present Indonesia is still in a concentrated epidemic where transmission is still concentrated in at-risk populations. So it needs concrete action so that MSM are aware of using condoms at risky sex.

Condom use is very important in sexual relations behavior. Condom use appears to be given to the role of sex as insertive and mixed. Anal sex behavior in the MSM group was reported to be mostly not using condoms. Statistical data related to the number of people with HIV / AIDS is increasing especially in MSM. A report from the Director General of Disease Control and Environmental Health (P2PL) in 2014 found data that the cumulative number of HIV / AIDS cases in Bali with estimates of 9,637 and AIDS 4,261 (Ditjen PP \& PL Kemenkes RI, 2014). Whereas if we look at the estimation by the Ministry of Health in 2013 that the number of MSM is very high, especially in Bali, Buleleng Regency with 2,060 pure MSM is affordable, this result shows that many MSM communities have not been reached for information on condom use at risky sexual relations (Kemenkes RI, 2013a).

Some research results showed that, the factors that can increase condom use in MSM are perceived susceptibility, perceived severity, perceived benefit and history of having an STI (Chandra et al., 2018). Availability of condoms and lubricants (Wardhani, Shaluhiyah, \& Demartoto, 2015). This study aims to see the most dominant factors related to condom use in MSM in Buleleng Regency.

\section{METHODS}

This study was a cross sectional in Buleleng Regency. Data was taken at the Center Health Center for MSM services, namely in the Buleleng Health Center 1. This health center serves MSM blood test, MSM outreach, counseling and ARV treatment assistance. The independent variables of this study were social media, sexual roles and a history of infectious infections with the dependent variable in the form of condom use.

The sampling technique used is snowball sampling by taking one respondent then taking the next respondent with the first sample information. Data collection techniques used closed interviews assisted by HIV / AIDS program holders by previously conducting trials and training to enumerators related to the questionnaire. Data were analyzed by univariate, bivariate and multivariate using software. The results of etbical clearances were obtained at the STIKES Buleleng ethics commission. 


\section{RESULTS AND DISCUSSION}

Socio-demographics of MSM as respondents varied greatly. Univariate analysis results can be seen in table 1 below.

Table 1. Frequency distribution of male sex male sexual behavior in Bali

\begin{tabular}{lc}
\hline Variables & $\mathbf{f ( \% )}$ \\
\hline Age (Mean \pm SD) & $25.28 \pm 7.8$ \\
$\leq 25$ Years & 55.2 \\
$>25$ years & 44.8 \\
\hline STI Knowledge & \\
Yes & $42(72.4)$ \\
No & $16(27.6)$ \\
\hline Condom Knowledge & \\
Yes & $50(86.2)$ \\
No & $6(10.3)$ \\
Doesn't answer & $2(3.4)$ \\
\hline Marriage Status & \\
Unmarried & $28(48.3)$ \\
Married / Divorced & $30(51.7)$ \\
\hline Education Status & \\
High Education & $40(69.0)$ \\
Low Education & $18(31.0)$ \\
\hline Perceived susceptibility & \\
Perceive high & $25(43,1)$ \\
Perceive low & $33(56,9)$ \\
\hline The Role ofSexual Relationships & $12(22.4)$ \\
Assertive & $20(34.5)$ \\
Receptive & $25(43.1)$ \\
Mixed & \\
\hline Availability of condoms & $47(81,0.3)$ \\
Sometimes & \\
never / rarely & \\
\hline Use of Condoms & \\
Using Condom & \\
Without Condom & \\
\hline & \\
\hline
\end{tabular}

Table 1 shows that the frequency distribution from the table above shows an average of 25 years with the majority of respondents namely $55.2 \%$ aged 25 years. Most of the respondents (72.4\%) knew about STIs and most of the respondents $(86.2 \%)$ knew about the function of condoms. Most MSM respondents are married / divorced and most of them are tertiary. The 
perception of susceptibility to each disease is very lacking for some respondents, which is as much as $56.9 \%$. This result also found that some respondents said that they could act as receptive or could be $43.1 \%$ insertive. After being asked about the availability of condoms, the majority of MSM said that rarely and until they never provided condoms when making an agreement for risky sexual intercourse that was $81.0 \%$. The results of the interview also found that only $20.7 \%$ of MSM used condoms during the last risky sex.

Then bivariate analysis was carried out to determine the factors that could enter into multivariate analysis. Following table 2 will explain the results of bivariate analysis.

Table 2. Cross tabulation of the dependent variable with condom use

\begin{tabular}{|c|c|c|c|}
\hline \multirow{2}{*}{ Variable } & \multicolumn{2}{|c|}{ Condom Use } & \multirow{2}{*}{$\begin{array}{c}\text { Value } \\
\mathrm{p}\end{array}$} \\
\hline & Using Condom & Without Condom & \\
\hline Marriage Status & & & $0.038 *$ \\
\hline Not married & $9(32,1)$ & $19(67.9)$ & \\
\hline Married / divorced & $3(10,0)$ & $27(90.0)$ & \\
\hline Education status & & & 0.23 \\
\hline HigherEducation & $10(25.0)$ & $30(75.0)$ & \\
\hline Low Education & $2(11,1)$ & $16(88.9)$ & \\
\hline STI Knowledge & & & 0.22 \\
\hline Yes & $7(16,7)$ & $35(83.3)$ & \\
\hline No & $5(32,1)$ & $11(68.8)$ & \\
\hline Knowledge of condom & & & 0.14 \\
\hline Yes (reff) & $9(18.0)$ & $41(82.0)$ & \\
\hline No & $3(50,0)$ & $3(50.0)$ & \\
\hline Doesn't answer & $0(0,0)$ & $2(100)$ & \\
\hline The Role ofSexual Relationships & & & $0,004 *$ \\
\hline Insertive & $7(53.8)$ & $6(46,2)$ & \\
\hline Receptive & $2(10,0)$ & $18(90,0)$ & \\
\hline Mixed & $3(12,0)$ & $22(88,0)$ & \\
\hline Perceived susceptibility & & & $0.012 *$ \\
\hline Perceived high & $9(36.0)$ & $16(64.0)$ & \\
\hline Perceived low & $3(9.1)$ & $30(90,9)$ & \\
\hline Availability of condoms & & & $0,024 *$ \\
\hline Sometimes & $5(45,5)$ & $6(54,5)$ & \\
\hline never / rarely & $7(14,9)$ & $40(85,1)$ & \\
\hline
\end{tabular}

Table 2 shows the tabulation of several factors that respondent status, the role of sexual realtionships, perceived susceptibility, and availability of condoms have relayionship with using condom. This factor can entered into multivariate analysis to see the most factorsrelated to condom use. 
Based on the results of the interviews, it was also found that the most widely stated reasons for MSM not using condoms can be seen in table 3 below.

Table 3. Analysis of the frequency of reasons for not using condoms for MSM

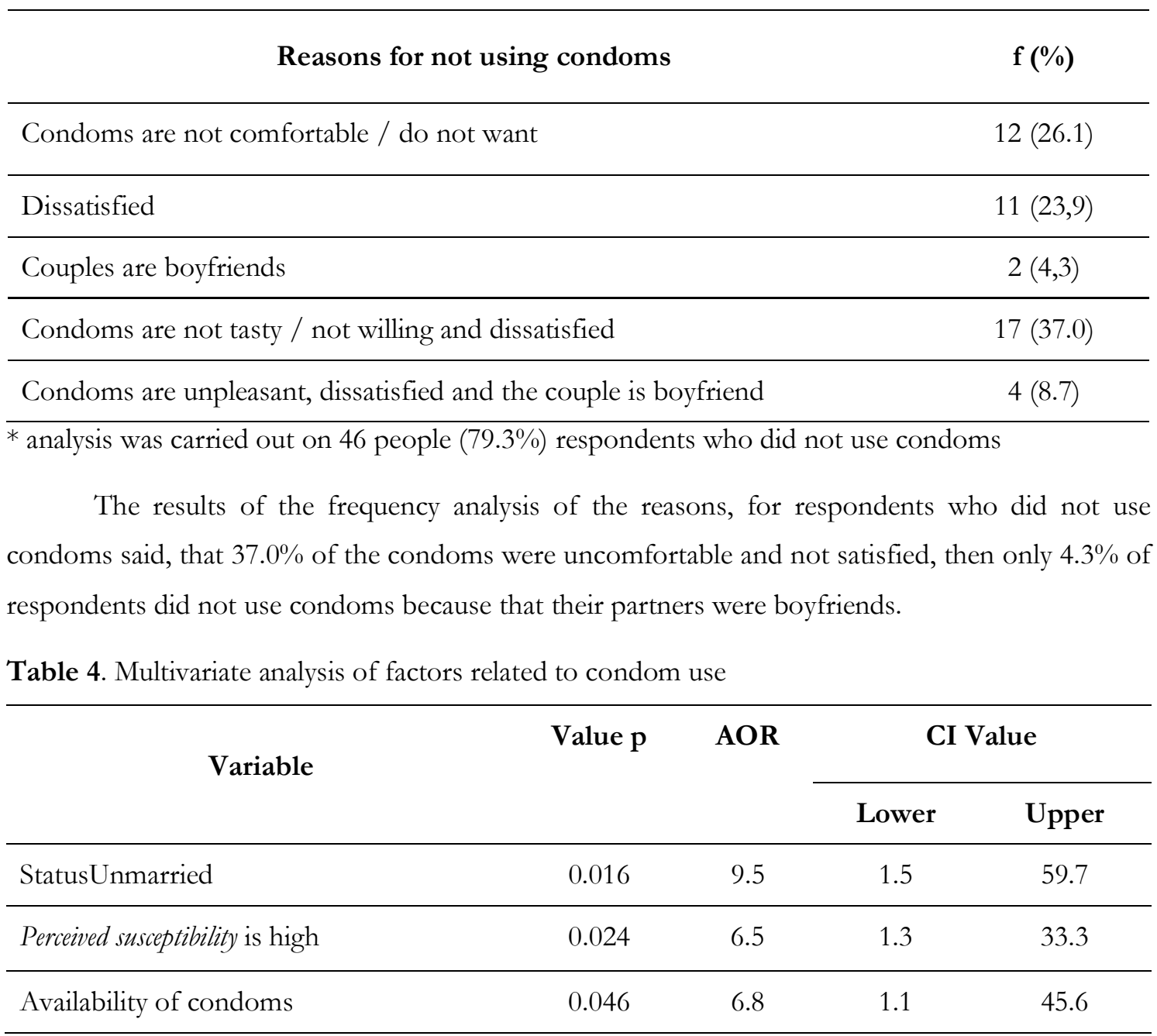

Table 4 shows the results of multivariate analysis which found that the factors associated with condom use when making a risky relationship were marital status, perceived susceptibility and availability of condoms. Marital status shows that unmarried respondents 9.5 times more likely to use condoms than married or divorced respondents (AOR: 9.5, 96\% CI 1.5-59.7). Then the perception of high MSM vulnerability is also related to condom use. High vulnerability perceptions were 6.5 times more increased using condoms than perceptions of lack of vulnerability (AOR: 6.5, $96 \%$ CI 1.3-33.3). Furthermore, the availability of condoms in place and carried by MSM is also a factor associated with condom use. The more frequently available condoms can increase condom use during sexual intercourse (AOR: 6.8, 96\% CI 1.1-45.6).

MSM is a marginalized community, so there is very little information that can be obtained by MSM, especially in preventing STIs or HIV / AIDS. Whereas MSM are very high risk condition because MSM are very active in having sexual intercourse with risk. The results of this study found that, only $20.7 \%$ of MSM used condoms during their last sexual intercourse. This result is very 
small and it shows that condom use is still very low in MSM. The results of this study are also in line with the results of the integrated behavioral biology survey (IBBS) which found that men who used condoms when paid sex, was also still very small at 30.1\% (Kemenkes RI, 2013b). The reason for not using condoms is also very classic, that the use of condoms is unpleasant and unsatisfied. This result is in line with the results of research in Papua, that the reason for not using condoms in men who sex with men is customers or quibble couples who do not want to use condoms (Lolong \& Pangaribuan, 2010). Low condom use indicates low knowledge of MSM related to the use and function of condoms. The results of this study found that some of the respondents, were educated only up to high school. Exposure to health information in depth is also difficult to obtain. This result is also supported by previous research that the majority of respondents who graduated from high school were equally desirous of conducting VCT examinations (Prawesti, Ketut, \& Armini, 2018).

The results of this study also found that the average age of pure MSM respondents were 25 years old and the majority of respondents were in the range of $\leq 25$ years. This result is also in line with previous research that most MSM respondents are still in the age range of 21-30 years. This shows that MSM perpetrators are still very easy and in the reproductive age range. If this continues to develop, so many young people will experience behavioral setbacks. Especially sexual disorientation (Prawesti et al., 2018).

After multivariate analysis, the dominant factors related to condom use of MSM were perceived susceptibility, availability of condoms and unmarried status of MSM. When viewed from vulnerability perceptions the results of this study indicate that the more MSM feel themselves vulnerable to IMS and HIV / AIDS favored so that 6.5 times behave using condoms during risky sex. This perception of vulnerability in the form of MSM feel themselves to know the knowledge of STIs and HIV / AIDS and feel themselves at risk for STIs and HIV / AIDS. This result is in line with the research conducted in Semarang, that the perception of MSM vulnerability will increasingly increase MSM to use condoms (Sidjabat, Setyawan, Sofro, \& Hadisaputro, 2017). Condom use can be carried out by MSM if there are demands that endanger them. MSM who have big worries such as fear of kissing people living with HIV / AIDS, doing oral sex without condoms, and ejaculating during anal sex will be one of the acts of transmission of HIV / AIDS. This is what enhances the perception of MSM vulnerability so they want to use condoms (Glanz, Rimer, \& Viswanath, 2008). Besides perceived susceptibility, another factor is the availability of condoms.

Availability of condoms is a behavior of MSM to always provide condoms during risky sexual intercourse through oral sex to anal sex. The results of this study indicate that it is very rare even to the absence of condoms owned by MSM. Only 19\% stated that condoms are sometimes available and taken alone during risky sexual intercourse. The results of the interviews reported that most respondents did not provide condoms because they were confused about where to buy and where to get. Then MSM, most of whom are still young, are ashamed to buy condoms either at the supermarket or at the pharmacy. Research in Semarang also found that most young MSM did not 
prepare condoms because they were embarrassed and had a negative stigma when buying condoms (Sidjabat et al., 2017).

Availability of condoms can increase 6.8 times MSM to use condoms when doing risky behavior. This result also appears in the research in Sintang that the availability of condoms can increase condom use in terms of the availability of condom facilities provided by the community concerned about MSM and AIDS. This will make it easier for MSM to obtain condoms to prevent STIs and HIV so that the fulfillment of infrastructure facilities is very important to improve. One of them is by providing condoms that are easy and easy to obtain by MSM (Asnol, 2016).

Another factor is the status of unmarried respondents 9.5 times can increase condom use for MSM. These results prove that there are still concerns about adolescents about condom use for those who are not married. From the results of interviews with respondents who used condoms and were not married they were afraid that they would later get STIs or HIV / AIDS which could affect their marriage later. This result is in line with previous research that most of the respondents who were unmarried and still in the status of students were more concerned with themselves by preventing condom use (Rokhmah \& Sudhirham, 2015). Different results were found in other studies that there was no relationship between marital status and condom use. This is because some respondents disregard social status between marriage, unmarried customs or other things (Handayani, Shaluhiyah, \& Cahyo, 2017). The use of condoms that are high in unmarried status indicates that MSM are open to information on condom use and are ready to continue to prevent STIs and HIV / AIDS, one of them is using condoms.

These results prove that although MSM are still very difficult to reach, but from the low behavior of condom use, it is necessary to provide information or health education related to the vulnerability of STIs and HIV / AIDS if they do not use condoms. Then the availability of condoms and unmarried status can also indicate the open mind of MSM to obtain information on the importance of condom use.

\section{CONCLUSION}

The conclusion of this study, there are several factors associated with condom use in MSM, namely marital status indicating that the respondents are unmarried (AOR: 9.5, 96\% CI 1.5-59.7). Then the high susceptibility perceptionof MSM was also related to condom use (AOR: 6.5, 96\% CI 1.3-33.3). Subsequently the availability of condoms on site associated with condom use of MSM (AOR: 6.8, 96\% CI 1.1-45.6).

\section{SUGGESTIONS}

In the future the MSM community are increasingly taken into account in providing health informationof condom use so that it can reduce the incidence of STIs and HIV / AIDS in MSM. Then the need for cooperation with policy maker and the availability of condoms must be easy to found by MSM. So that they can take preventive behavior properly during risksexual behavior. 


\section{REFERENCES}

Asnol, U. (2016). Perilaku Konsisten Waria yang Bekerja di Salon Menggunakan Kondom Untuk Pencegahan HIV dan AIDS di Kecamatan Sintang. Wawasan Kesehatan, 2 Nomor 2, 25-50.

Beyrer, C., Baral, S., Sifakis, F., \& Cleghom, F. (2012). Global Epidemiologi of HIV Infection in men who have sex with men. Lancet, 367-377.

Chandra, P., Shaluhiyah, Z., \& Cahyo, K. (2018). Analisis Faktor-Faktor Yang Berhubungan Dengan Pemakaian Kondom Dan Pelicin Pada Lelaki Seks Lelaki (LSL) Sebagai Upaya Pencegahan HIV (Studi Kuantitatif Pada Semarang Gaya Community). Jurnal Kesehatan Masyarakat, 6 Nomor 1.

Ditjen PP \& PL Kemenkes RI. (2014). Statistik Kasus HIV/ AIDS di Indonesia. Jakarta.

Glanz, K., Rimer, B., \& Viswanath, K. (2008). Health Behavior and Health Education. Teory Research \& Practice.

Handayani, R., Shaluhiyah, Z., \& Cahyo, K. (2017). Faktor Faktor yang Mempengaruhi Perilaku Pemakaian Kondom Konsisten Saat Melakukan Hubungan Seksual pada Laki-Laki Pengguna Napza di Kota Semarang. Jurnal Promosi Kesehatan Indonesia, 12 Nomor 1, 134151.

Kemenkes RI. (2013a). Size Estimation of Key Affected Populations (KAPs).

Kemenkes RI. (2013b). Survei Terpadu Biologis dan Perilaku Pada Masyarakat Umum di Tanah Papua. Jakarta.

Kemenkes RI. (2014). Profil Kesehatan Indonesia 2014. Jakarta.

Lolong, D. B., \& Pangaribuan, L. (2010). Perilaku Penggunaan Kondom Dalam Pencegahan Penularan HIV Pada Masyrakat Umum di Tanah Papuan dan Pada Kelompok Risiko di Indonesia, 2004-2006. Jurnal Ekologi Kesehatan, 9 No.1, 1144-1154.

Prawesti, N. A., Ketut, N., \& Armini, A. (2018). Faktor Pendorong Pemanfaatan Layanan Voluntary Counselling And Testing (VCT) Oleh Lelaku Suka Dengan Lelaki (LSL) DI LSM Gaya Nusantara (Factor Related Voluntary Counselling And Testing Utilization By Men Sex With Men ( MSM ) In Gaya Nusantara Civil Soci. Jurnal Ners Dan Kebidanan, 5 Nomor 2, 129-136. https://doi.org/10.26699/jnk.v5i2.ART.p129

Rokhmah, D., \& Sudhirham, O. (2015). Youth and HIV / AIDS : Sexual lifestyle of youth MSM ( man who have sex with man ) and its risk towards HIV and AIDS infection, 3(4), 89100.

Ruxrungtham, K., Brown, T., \& Phanuphak, P. (2004). HIV/AIDS in Asia. The Lancet, 364, 69.

Sidjabat, F., Setyawan, H., Sofro, M., \& Hadisaputro, S. (2017). Lelaki Seks Lelaki, HIV/AIDS dan Perilaku Seksualnya di Semarang. Jurnal Kesehata Reproduksi, 8 Nomor 2, 131-142.

Wardhani, P., Shaluhiyah, Z., \& Demartoto, A. (2015). Perilaku Penggunaan Kondom dan Pelicin pada LSL di Kota Surakarta. Promosi Kesehatan Indonesia, 10 Nomor 1, 89-101. 